\title{
Workshops as a democratic proposal in order to change the supervision work in nursing
}

\author{
Oficinas como proposta democrática para mudanças no trabalho da supervisão em enfermagem \\ Talleres como propuesta democrática para cambios en el trabajo de supervisión en enfermería
}

\author{
Maria Silvia Teixeira Giacomasso Vergílio', Vanessa Pellegrino Toledo', Eliete Maria Silva' \\ ' Universidade Estadual de Campinas. Campinas, São Paulo, Brazil.
}

How to cite this article:

Vergílio MSTG, Toledo VP, Silva EM. Workshops as a democratic proposal in order to change the supervision work in nursing. Rev Bras Enferm [Internet]. 2018;71(4):2050-4. DOI: http://dx.doi.org/10.1590/0034-7167-2017-0286

Submission: 05-06-2017 Approval: 06-22-2017

\begin{abstract}
Objective: to report the experience of developing workshops as an intervention strategy in an action research, aiming to review the work of supervision in hospital nursing. Method: to report of the experience of planning, developing and evaluating workshops with a psychosocial approach. Three workshops were held, in a reserved place, with the participation of 21 supervisors of a public university hospital. Each workshop was organized with heating, day work, closure with syntheses and consensus. Results: the work provided the exchange of experiences, reflections and proposals for difficulties identified in the work process that distract supervisors from the management of assistance such as communication failure, reworking and lack of definition of assignments in the team. Conclusion: the dynamics of the workshops favored supervisors to propose solutions to the difficulties of their practice in a more democratic and participative way, through dialogical interactions, sharing of the feelings pertinent to the work context and establishing consensus for the completion of the task.
\end{abstract}

Descriptors: Nursing supervision; Hospital Nursing Service; Education; Hospital Administration; Organization and Administration.

\section{RESUMO}

Objetivo: relatar a experiência de desenvolver oficinas como estratégia de intervenção em uma pesquisa-ação, visando rever o trabalho da supervisão em enfermagem hospitalar. Método: relato da experiência de planejar, desenvolver e avaliar oficinas com abordagem psicossocial. Foram realizadas três oficinas, em local reservado, com a participação de 21 supervisores de um hospital público universitário. Cada oficina foi organizada com aquecimento, trabalho do dia, fechamento com sínteses e consensos. Resultado: o trabalho proporcionou trocas de experiências, reflexões e propostas para dificuldades identificadas no processo de trabalho que afastam os supervisores do gerenciamento da assistência como a comunicação falha, o retrabalho e a indefinição de atribuições na equipe. Conclusão: a dinâmica das oficinas favoreceu aos supervisores propor ações para soluções das dificuldades da sua prática de forma mais democrática e participativa, mediante interações dialógicas, partilha dos sentimentos pertinentes ao contexto de trabalho e estabelecimento de consensos para a finalização da tarefa.

Descritores: Supervisão de Enfermagem; Serviço Hospitalar de Enfermagem; Educação; Administração Hospitalar; Organização e Administração.

\section{RESUMEN}

Objetivo: relatar la experiencia de desarrollar talleres como estrategia de intervención en una investigación-acción, buscando revisar el trabajo de la supervisión en enfermería hospitalaria. Método: relato de la experiencia de planear, desarrollar y evaluar talleres con abordaje psicosocial. Se realizaron tres talleres, en local reservado, con la participación de 21 supervisores de un hospital público universitario. Cada taller fue organizado con calentamiento, trabajo del día, cierre con síntesis y consensos. Resultado: el trabajo proporcionó intercambios de experiencias, reflexiones y propuestas para dificultades identificadas en el proceso de trabajo que alejan a los supervisores de la gestión de la asistencia como la comunicación falla, el retrabajo y la indefinición de atribuciones en el equipo. Conclusión: la dinámica de los talleres favoreció a los supervisores proponer acciones 
para soluciones de las dificultades de su práctica de forma más democrática y participativa, mediante interacciones dialógicas, compartiendo los sentimientos pertinentes al contexto de trabajo y establecimiento de consensos para la finalización de la tarea. Descriptores: Supervisión de Enfermería; Servicio Hospitalario de Enfermería; Educación; Administración Hospitalaria; Organización y Administración.

\section{INTRODUCTION}

In the managerial practice of nursing work is the activity of supervision as an intermediary element that integrates managers at the central level (planners) with professionals from the (operational) nursing team and other professionals directly and indirectly involved in the care, guiding them in order to carry out what was planned and at the same time managing the demands of personnel and materials, tensions and conflicts between work teams, as well as other daily issues ${ }^{(1-2)}$.

This characteristic of supervision, as an element of connection and knowledge of the institutional dynamics, gives the nursing professional a strategic position for reflective action on how to manage care in the hospital environment, promoting changes in the thinking and acting of the nursing team and planning the care in which one considers the subjectivity of patients and not only the control of compliance with clinical techniques and protocols ${ }^{(2)}$.

In general, the national literature points to the potential of supervision to improve care quality by integrating care and management processes in a systematized and reflexive manner, planning actions, acting with data bases, evaluating results with the ability to undertake and carry out innovative actions ${ }^{(1,3)}$.

In the international literature, there have been studies, since the 1990s, on a practice called clinical supervision, focused on competence development and reflective capacity, which guides nurses in the planning of care, providing support for decision making in interventions. To that end, models have been developed that systematize their practice, showing positive results for the assistance with greater leadership abilities of supervised nurses, reduction of errors, improvement in motivation to work with stress reduction and dissatisfaction ${ }^{(4)}$.

In view of the above, it is considered that nursing supervision plays a fundamental role in the management of care, with the potential to change the way nurses work, approaching more reflective practices according to international experiences, overlapping with control and organization of the therapeutic environment observed in the present day ${ }^{(1-4)}$.

With this motivation, the researchers developed this study with the objective of reviewing the work process of nursing supervision, in order to build, together with the group of supervisors, a proposal for action that overcomes the difficulties that distract them from the management of care. For this, we opted for the qualitative approach, based on the work process referential, based on the Research-Action (RA) methodology.

RA is a type of social research, with origins in Kurt Lewin's studies on the dynamics of small groups held in the 1940s. PA is developed in a collaborative and democratic process of investigation in which researchers and members of the institution work together in a critical and participatory way to diagnose and propose solutions to a situation or problem identified ${ }^{(5)}$. In nursing, RA has been developed to produce knowledge in various areas of action, as well as diagnosis of the team, relationships and work environment to signal a mobilizing strategy for managers and institutional support aimed at promoting effective changes ${ }^{(6)}$.

This study counted on the participation of researchers from the Nursing Department (DEnf) and supervisors, from the development of the project, planning the actions of each phase, evaluations, validation of the results presented in meetings respecting the interests of the group and actions.

The study was conducted in four phases: the first was intended to understand the work process of supervision; in the second, participant observation was carried out, which allowed the interlocution with the group of supervisors; in the third, actions were developed through workshops and, finally, the fourth phase of evaluation was presented, which took place throughout the research process.

The results of the first phase, through interviews with supervisors and nurses, showed that the supervision work is fragmented in the 24 hours, with communication difficulties for the continuity of care between the day and night periods. Supervision actions are focused on work control, mainly focused on the frequency of the nursing team and availability of materials, responding to the unexpected demands that hinder the continuity of the planning performed by the Nursing Services, especially regarding the follow-up of the activities of the assistance management. Observations and monitoring of supervisors' activities, in the second phase, validated the results of the first and subsidized the planning of actions of the third phase.

For the development of the third phase, the "workshops" method was chosen because they understood that they were planned spaces in meetings, regardless of the number, destined to work with small groups for the collective construction of a task ${ }^{(7)}$.

The practice of workshops is not recent, but is widely disseminated as a privileged device to promote reflection and critical awareness in a collective work, being employed in several areas, such as psychology for psychotherapeutic interventions, education for pedagogical training in the sector management skills for managers ${ }^{(7-9)}$. The national literature, after the 1990s, shows its use in nursing in educational interventions for several patients (chronic, pregnant, adolescents, caregivers), therapeutic care in mental health, in research ${ }^{(9)}$, identifying a gap for the professional development in the nursing management area. In the international literature, in addition to those cited, workshops are efficient for the training of professionals in obtaining research skills and expert knowledge to implement evidence in their practice ${ }^{(10)}$. 
It is considered to develop workshops as a strategy appropriate to the guiding principles of action research, in which participants construct proposals for problem solving with the support of the researcher, through dialogues and consensus-building to seek solutions capable of bringing about change once that the research group is knowledgeable about culture and institutional reality. Another determining factor for the choice of workshops was their democratic and participative character ${ }^{(7-8)}$, as it was intended to provide supervisors with a differentiated strategy of traditional skills with knowledge transmission, providing them with a space for reflection and socialization of their experiences for this group.

In view of the above, the purpose of this article was to report the experience of the workshop development as a strategy used for the intervention phase of a RA, in which the proposal, based on collective construction was based on changes in the work process of supervision of nursing.

\section{Methodological course of the workshops}

This is an experience report of the planning, development and evaluation of workshops, carried out with nursing supervisors.

The research was developed in the DEnf of a large (405 beds) and high complexity university hospital linked to the Unified Health System (SUS). The DEnf has 1,447 operational professionals among nurses, nursing technicians and nursing auxiliaries, sized to work in all the units of the hospital. Supervision involves 25 supervisors, who respond hierarchically to the Director of Service, eight in the evening (7 pm-7 am) and the rest in the daytime at flexible hours for follow-up of morning shifts (7 am-1 pm) and in the afternoon (1 pm-7 pm).

The workshop method used proposes a psychosocial approach, based on the contribution of several theories that are articulated to help coordination in understanding the dynamics and evolution of the group. This theoretical articulation encompasses three dimensions: 1) psychosocial dimension for understanding group dynamics with contribution of Kurt Lewin's Field Theory, 2) psychodynamic dimension of groups found in authors such as Freud, Bion, Foulkes and Pichon-Rivière, and 3) educational dimension based on the pedagogy of autonomy of Paulo Freire ${ }^{(7)}$.

\section{Planning and organization of workshops ${ }^{(7)}$}

The demand on the need to review the supervision work process was proposed by the researchers and agreed with the Board of the DEnf, enabling support for the participation of all supervisors, day and night. However, what has been worked on in this vast field has emerged from the results of the first phase of the project and confirmed by the researcher's interlocution in the monitoring of the daily routine of supervisors in the hospitalization unit during the second phase. In this way, the task agreed with the participant group, that is, the purpose of the workshops was established in: to discuss the activities carried out by the supervisors and to determine what is or not approximates the purpose of the work, the management of the assistance, to propose changes in the work process compatible with the institutional reality.

The composition of the group for the coordination of the workshops was established between the researcher (with the responsibility of coordinating the workshops), two nurses from the Continuing Education (CE) and a teacher from the University of Nursing/Unicamp, and research, as supporters in planning, organizing, discussing, recording meetings and evaluations.

For the organization and planning of the workshop structure, three preparatory meetings were held in which the workshop coordination group participated with the DEnf board. At these meetings the expectations were discussed and the consensus was established on the purpose and responsibilities of nursing supervision in the institution. Such alignment of concepts and ideas was fundamental for the construction of the guiding axis for the work of the workshops (Figure 1).

A flexible plan with a general plan was developed as a guide for each workshop, containing in its sequence themes and strategies that stimulated the group's critical awareness of the task. The plan was reviewed by the coordination of the workshops after each meeting, considering the individual evaluations of the participants, the dynamics of the group, the content of the discussions, the production of the day and the participants' involvement in the task.

The structure of the workshops was composed of three moments ${ }^{(7)}$. In the first moment were carried out recreational activities, chosen according to the theme worked in the workshop, for sensitization and relaxation of the group. In the second moment, activities called "work of the day" were organized to mobilize discussions, reflections and encourage their production. In the third moment, the finalization, with systematized exposure by the production coordinator and conflicting issues of the day seeking consensus and validation by the group producing a synthesis and evaluation of the meeting. Chart 1 presents a standard structure of workshops.

Three workshops were initially scheduled, three hours each, according to the possibility offered by the DEnf, in a reserved place, outside the work environment, in order to guarantee the privacy and unconcern of the daily tasks.

We clarify the opportunity to have a space reserved to share experiences, anguish and criticism about the supervisory work process, to construct proposals for changes.

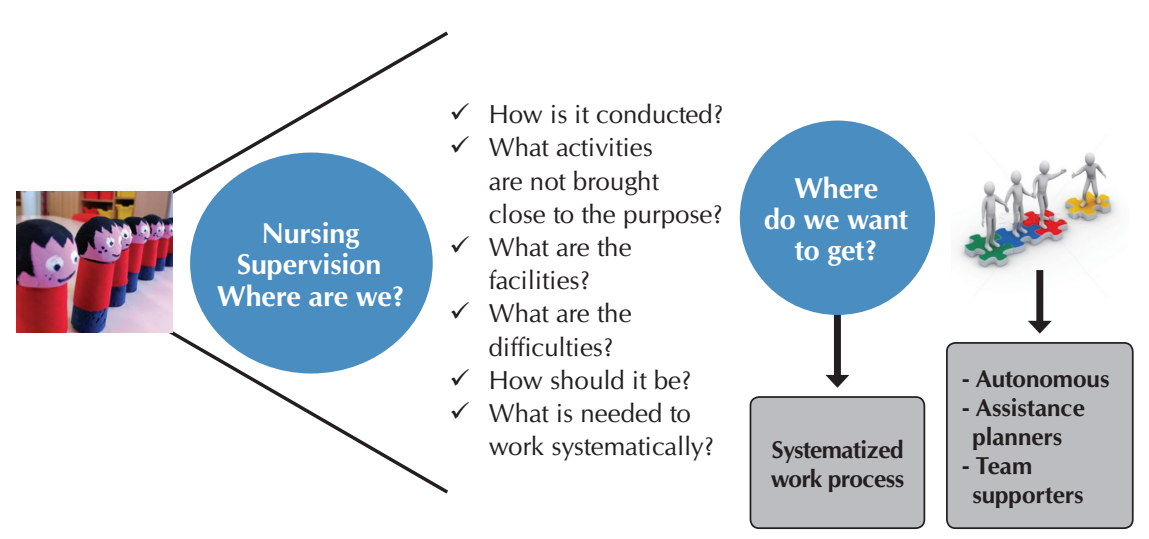

Figure 1 - Workshop guiding axis with nursing supervisors, October, 2016 
Chart 1 - Standard structure of workshops with nursing supervisors, October, 2016

\begin{tabular}{|l|l|l|}
\hline \multicolumn{1}{|c|}{ Activities } & \multicolumn{1}{c|}{ Tasks } \\
\hline Presentation & $\begin{array}{l}\text { Presentation of the coordinator, supporters and workshops. Participation agreement, } \\
\text { validation and consensus on the task. }\end{array}$ & 10 min \\
\hline Sensitization and relaxation & Dynamics: do you accept the challenge? & 15 min \\
\hline Work of the day & Individual work: answer worksheet questions. & 20 min \\
\cline { 2 - 3 } & $\begin{array}{l}\text { Organization in four subgroups. } \\
\text { Work in subgroups: discussions based on individual issues, reach consensus and respond } \\
\text { to the group worksheet. } \\
\text { Recording of the synthesis of the subgroup by the rapporteur. }\end{array}$ & 45 min \\
\hline Break & Coffee. & 15 min \\
\hline Presentation & Subgroup reporters presented the result of the study. & 20 min \\
\hline Closure & Discussions of presentations, synthesis of works and consensus. & 15 min \\
\hline Evaluation and conclusion & $\begin{array}{l}\text { Individual evaluation in own instrument. } \\
\text { Agreements for the next meeting. }\end{array}$ & \\
\hline
\end{tabular}

Source: according to Afonso, $2010^{(7)}$

Figure 1, the guiding axis of the workshops, was presented at the moment for the group's reflection on "where we are" and, as we work, for "where we want to get" with the supervision work in nursing and the supervisor's expected attitudes.

The issues highlighted in the center of Figure 1 were worked over the three meetings, stimulating criticism and reflection. The discussions between the participants allowed the problematisation of the practice through reports about the experiences, provoking internal noises and conflicts marked by the perception of the differences of performance. The reports were loaded with anxieties, and sometimes "phrases filtered" by noise outside the group, determined by the culture of a public institution, with hierarchical power relations and, currently, with a strong reduction of financial resources, lack of materials, causing relationships conflicts between peers and support services (pharmacy, laboratory and others).

The evaluation of the work was done through the coordination of the workshops, through the recording of the narratives, observation of the attitudes, behaviors and production of the group, considering the combination of two dimensions: the most objective external task, focused on what it was proposed to achieve and the task more subjective, related to the growth of the group ${ }^{(7)}$.

After three months of the workshops, we sent an online questionnaire to the participant group to follow up and evaluate the understanding of the workshops as a space for reflection on the work and the accomplishment of the proposed activities.

It was emphasized that the ethical-legal precepts of research were followed and the participants were oriented about the objectives and secrecy. After clarifying their doubts, it was requested the signing of the Free and Clarified Consent Term - FCCT. The research was approved by the Research Ethics Committee of Unicamp/Campinas Campus, under the number 887.936.

\section{Results evaluation of the workshops}

- The three three-hour meetings (totaling 9 hours) were not enough to complete the task due to the involvement of the participants in the discussions and it was necessary to add two more meetings (adding another 6 hours, totaling 15 hours) organized by the group, showing their commitment to the completion of the task. The time planned for the work is not always coincident with the internal processes of the group's elaboration, therefore, it is necessary to clarify, in the institution as well as with the participants, the possibility of flexible planning of both time and content and strategies ${ }^{(7-8)}$.

- Twenty-one supervisors participated, as two were on vacation and two were impeded by other professional commitments. This number was evaluated as excessive, making it difficult to evolve the discussions. In the work in subgroups, with about 6 people, the participation and interaction occurred with greater intensity and better interactivity. In the literature it is recommended the formation of groups of 5 to 12 people, so as not to generate subgroups with crystallized ideas that hamper the democratic process of agreements and consensus ${ }^{(8)}$.

- As for the group dynamics, the workshops provided the group with discussions and exchanges of experiences and difficulties. The preserved space was fundamental for the dialogue about some recurrent difficulties, related to the hierarchical superior level, as the lack of feedback of the work, lack of communication and lack of definition of responsibilities for some tasks pointed out as performed with rework. After analysis, it was concluded that the moments of the group dynamics discussion, the internal task, were necessary and fundamental for the participants to evolve in their identification as a group if they were sensitized to the existence of differences of performance between the daytime and nighttime periods and, thus achieving the necessary cohesion to focus and complete the external task.

- As for the completion of the external task, the group collectively constructed a proposal to solve the emerging difficulties of daily life, containing a plan of actions, strategies, schedule and those responsible for each one, called "Shared management of assistance" composed of three activities for its operationalization: 1) review the management of care work in the $24 \mathrm{~h}, 2$ ) improve institutional communication and 3) review rework between supervisors, directors, nurses and administrative staff. This proposal was presented by a representative of the supervisors, by oral explanation and signed document of all the supervisors in a meeting attended by supervisors, directors 
and assistants of the DEnf. There was discussion about each activity and agreement for its accomplishment.

- The workshops were evaluated after three months, by online questionnaire, by $67 \%$ of the participants. In the affirmative, "Workshops as a space for reflection on work", 50\% of partial agreement, $35.7 \%$ of the total and $14.3 \%$ of partial disagreement were obtained, justified by the excessive number of participants. Regarding the accomplishment of activities 1, 2 and 3, mentioned above, $64 \%$ stated that they are made partially, $22 \%$ stated that they are not performed and $14 \%$ that they are carried out integrally. We believe that the discrepancy in achievement is due to the lack of unicity of behaviors in the nursing services, a fact that was also pointed out by the supervisors in the workshops.

\section{FINAL CONSIDERATIONS}

The workshop method provided an environment conducive to dialogic interactions, respecting differences, according to what is expected of a democratic and participatory process, as well as the involvement and engagement of the group to carry out the proposed objectives. In this democratic process, by having free expression of their anguish and dissatisfaction expressed by the lack of autonomy, lack of support and discredit, supervisors were strengthened in their group identity, reflecting on new possibilities for a different performance of "carrying out and making tasks be carried out", overcoming daily difficulties that deviate them from the purpose of their work. In this way, we evaluated that the workshops were an intense experience in the institution studied, being a positive and innovative strategy for a group accustomed to the traditional technical capacities that focus on the transmission of knowledge.

For the coordinator and the supporters, the development of the workshops was a continuous, arduous and at the same time pleasurable challenge, as the group's progress was monitored. The constant evaluations before and after meetings allowed us to understand the movement of the group and to strengthen its internal process of belonging, communication, cooperation, learning and production.

It is concluded that the workshop method can contribute to similar institutions, being an efficient strategy for nursing managers to develop critical awareness about internal processes covered by blocked communication and crossed by institutionalized power relations. This awareness movement is necessary and fundamental in the discussions about changes in the work processes, without which they will not fail to reproduce attitudes and behaviors restricted to the control of the work for real transformations of the supervision practices aligned with the purpose of the management of the assistance.

\section{ACKNOWLEDGMENT}

Sincere thanks to the Board of the Nursing Department and Continuing Education for support, partnership and involvement in the development of the research.

\section{REFERENCES}

1. Soares MI, Camelo SHH, Resck ZMR, Terra FS. Nurses' managerial knowledge in the hospital setting. Rev Bras Enferm[Internet]. 2016[cited 2017 Feb 03];69(4):631-7. Available from: http://www.scielo.br/pdf/reben/v69n4/en_0034-7167-reben-69-04-0676.pdf

2. Silva EM. Supervisão como essência do gerenciamento em enfermagem. In: Vale EG, Peruzzo SA, Felli VEA, (Orgs.). PROENF Programa Atualização em Enfermagem: Gestão: Ciclo 03. Porto Alegre: Artmed/Panamericana; 2014. p.79-107.

3. Hausmann M, Peduzzi M. Articulação entre as dimensões gerencial e assistencial do processo de trabalho do enfermeiro. Texto Contexto Enferm[Internet]. 2009[cited 2014 Mar 15];18(2):258-65. Available from: http://www.scielo.br/pdf/tce/v18n2/08.pdf

4. Dilworth S, Higgins I, Parker V, Kelly B, Turner J. Finding a way forward: a literature review on the current debates around clinical supervision. Contemp Nurse[Internet]. 2013[cited 2014 Mar 15];45(1):22-32. Available from: https://www.ncbi.nlm.nih.gov/ pubmed/24099223

5. Tanajura LLC, Bezerra AAC. Pesquisa-ação sob a ótica de René Barbier e Michel Thiollent: aproximações e especificidades metodológicas. Rev Eletr PesquisEdu[Internet]. 2015[cited 2017 Jan 10];7(13):10-23. Available from: http://periodicos.unisantos. br/index.php/pesquiseduca/article/view/408

6. Silva AP, Munari DB, Brasil VV, Chaves LDP, Bezerra ALQ, Ribeiro LCM. Trabalho em equipe de enfermagem em unidade de urgência e emergência na perspectiva de Kurt Lewin. Ciênc Cuid Saúde.[Internet]. 2012[cited 2017 Jan 10];11(3):549-56. Available from: http://www.periodicos.uem.br/ojs/index.php/CiencCuidSaude/article/view/16609/pdf

7. Afonso MLM, (Org.). Oficinas: em dinâmica de grupos na área da saúde. 2a Ed. São Paulo, SP: Casa do psicólogo; 2010.

8. Spink MJ, Meganon VM, Medrado B. Oficinas como estratégia de pesquisa: articulações teórico-metodológica a aplicações éticaspolíticas. Psicol Soc[Internet]. 2014.[cited 2016 Nov 22];26(1):32-43. Available from: http://www.scielo.br/pdf/psoc/v26n1/05.pdf

9. Amaral MA, Fonseca RMGS. A oficina de trabalho como estratégia educativa com adolescentes na área de sexualidade. Rev Min Enferm[Internet]. 2005[cited 2017 Jun10];9(2):168-73. Available from: http://www.reme.org.br/artigo/detalhes/457

10. Yost J, Ciliska D, Dobbins M. Evaluating the impact of an intensive education workshop on evidence-informed decision making knowledge, skills, and behaviours: a mixed methods study. BMC Med Educ[Internet]. 2014[cited 2017 Jun 10];14:13. Available from: https:// www.ncbi.nlm.nih.gov/pubmed/24433582 